\title{
Distinct Clinical Courses in Type 1 Diabetes Mellitus Induced by Peg-interferon- $\alpha$ Treatment for Chronic Hepatitis C
}

\author{
Masanori Yamazaki, Ai Sato, Teiji Takeda and Mitsuhisa Komatsu
}

\begin{abstract}
We report two cases of type 1 diabetes mellitus (T1DM) which developed after interferon (IFN) therapy for chronic hepatitis $\mathrm{C}$. The patients had experienced abrupt hyperglycemia with positive anti-glutamic acid decarboxylase antibodies, resulting in initiation of insulin therapy. In one case, insulin therapy could be discontinued because endogenous insulin secretion was preserved at the onset and pancreatic $\beta$ cell function was recovered thereafter. In the other case with Hashimoto's thyroiditis and Sjögren's syndrome, continuation of insulin therapy was necessary because blood glucose levels were unstably controlled. Lasting autoimmunity superior to immunosuppressive mechanism may be associated with distinct clinical courses in these cases.
\end{abstract}

Key words: type 1 diabetes mellitus, chronic hepatitis $\mathrm{C}$, interferon

(Inter Med 49: 403-407, 2010)

(DOI: 10.2169/internalmedicine.49.2656)

\section{Introduction}

Interferon (IFN) is a cytokine with various biological actions such as antiviral and anti-tumoral activity; it regulates immune responses and cell differentiation. Type 1 interferons (IFN- $\alpha, \omega, \beta$ ) enhance cell-mediated immunity by increasing the expression of MHC class 1 antigens and augment cytotoxic activity of $\mathrm{NK}$ and $\mathrm{CD}^{+}$cells. However, the excessive actions can trigger the onset of autoimmune diseases (1).

Combined administration of peg-IFN with ribavirin is a standard therapy of chronic hepatitis C, whereas IFN therapy can induce type 1 diabetes mellitus (T1DM). We encountered 2 cases of T1DM provoked by IFN therapy for chronic hepatitis $\mathrm{C}$. The cases resulted in different clinical courses with regard to insulin requirement for management of diabetes.

\section{Case Report}

\section{Case 1}

A 46-year-old woman was diagnosed as having chronic hepatitis $\mathrm{C}$ on health examination in 2003. She had no family history of diabetes mellitus (DM), no drinking habit and no history of blood transfusion. She had been treated with peg-IFN- $\alpha 2 \mathrm{a}$ (180 $\mu \mathrm{g}$ once a week) or peg-IFN- $\alpha 2 \mathrm{~b}(80-150$ $\mu \mathrm{g}$ once a week) plus ribavirin in a hospital from March 2004 to March 2006. Fasting blood glucose levels before and after treatment were $89 \mathrm{mg} / \mathrm{dL}$ and $91 \mathrm{mg} / \mathrm{dL}$, respectively. Four weeks after treatment for 48 weeks she had begun to feel thirst which worsened gradually. She was referred to our hospital. On admission she was $156.1 \mathrm{~cm}$ tall and weighed $64.6 \mathrm{~kg}$ (BMI $\left.26.5 \mathrm{~kg} / \mathrm{m}^{2}\right)$. Laboratory data is shown in Table $1 . \mathrm{HbA}_{\mathrm{lc}}$ levels were high. Ketone bodies were detected in urine without acidemia. Autoantibodies to glutamic acid decarboxylase (GADAbs) showed high titers, while autoantibodies to insulinoma-associated protein 2 were negative. Serum and urinary C-peptide immunoreactivities

Department of Aging Medicine and Geriatrics, Division of Medicine, Institute on Aging and Adaptation, Shinshu University Graduate School, Matsumoto

Received for publication July 4, 2009; Accepted for publication November 4, 2009

Correspondence to Dr. Masanori Yamazaki, macha@shinshu-u.ac.jp 
Table 1. Laboratory Data of Two Cases

\begin{tabular}{|c|c|c|c|c|c|c|c|}
\hline Case & 1 & 2 & & & 1 & 2 & \\
\hline$C B C$ & & & & $\mathrm{IgG}$ & 1969 & 3005 & $\mathrm{mg} / \mathrm{dL}$ \\
\hline White blood cell & 5720 & 3580 & $/ \mu \mathrm{L}$ & $\operatorname{IgM}$ & 139 & 107 & $\mathrm{mg} / \mathrm{dL}$ \\
\hline Neutrophils & 72 & 20 & $\%$ & $\operatorname{Ig} \mathrm{A}$ & 288 & 307 & $\mathrm{mg} / \mathrm{dL}$ \\
\hline Lymphocytes & 62.6 & 29.3 & $\%$ & Tumor marker & & & \\
\hline Red blood cell & 4.70 & 4.07 & $\times 10^{6} / \mu \mathrm{L}$ & $\alpha$-fetoprotein & 4.2 & 5.6 & $\mathrm{ng} / \mathrm{mL}$ \\
\hline Hemoglobin & 14.2 & 12.2 & $\mathrm{~g} / \mathrm{dL}$ & SIL-2R & --- & 480 & $\mathrm{U} / \mathrm{mL}$ \\
\hline Hematocrit & 43.6 & 36.7 & $\%$ & Diabetes-related & & & \\
\hline Platelet & 20.1 & 17.8 & $\times 10^{4} / \mu \mathrm{L}$ & FBG & 263 & 172 & $\mathrm{mg} / \mathrm{dL}$ \\
\hline Urinalysis & & & & HbAlc & 13.9 & 7.1 & $\%$ \\
\hline Glucose & $(3+)$ & $(-)$ & & S-CPR (fasting) & 1.5 & 0.4 & $\mathrm{ng} / \mathrm{mL}$ \\
\hline Protein & $(-)$ & $(-)$ & & U-CPR & 44.1 & 7.6 & $\mu \mathrm{g} /$ day \\
\hline Ketone bodies & $(3+)$ & $(-)$ & & Anti-GAD Abs & 42700 & 1320 & $\mathrm{IU} / \mathrm{mL}$ \\
\hline Blood Chemistry & & & & Thyroid-related & & & \\
\hline Total protein & 7.4 & 8.5 & $\mathrm{mg} / \mathrm{dL}$ & $\mathrm{T} 3$ & 134 & 122 & $\mathrm{ng} / \mathrm{dL}$ \\
\hline Albumin & 4.0 & 4.1 & $\mathrm{mg} / \mathrm{dL}$ & $\mathrm{T} 4$ & 10.3 & 8.1 & $\mu \mathrm{g} / \mathrm{dL}$ \\
\hline Total bilirubin & 0.43 & 0.60 & $\mathrm{mg} / \mathrm{dL}$ & TSH & 2.190 & 2.990 & $\mu \mathrm{IU} / \mathrm{mL}$ \\
\hline ALT & 106 & 12 & $\mathrm{IU} / \mathrm{L}$ & TBG & 33.2 & 21.3 & $\mu \mathrm{g} / \mathrm{mL}$ \\
\hline AST & 97 & 20 & $\mathrm{IU} / \mathrm{L}$ & Anti-TPO Abs & 4.5 & 879 & $\mathrm{IU} / \mathrm{mL}$ \\
\hline ALP & 361 & 222 & $\mathrm{IU} / \mathrm{L}$ & Anti-Tg Abs & 5.4 & 11205 & $\mathrm{IU} / \mathrm{mL}$ \\
\hline$\gamma$-GTP & 34 & 12 & $\mathrm{IU} / \mathrm{L}$ & Immunity & & & \\
\hline Amylase & 73 & 174 & $\mathrm{IU} / \mathrm{L}$ & $\mathrm{CD}^{+}$ & 36.0 & 38.0 & $\%$ \\
\hline Total cholesterol & 156 & 185 & $\mathrm{mg} / \mathrm{dL}$ & $\mathrm{CD}^{+}{ }^{+}$-HLA-DR ${ }^{+}$ & 13.7 & 12.5 & $\%$ \\
\hline HDL-cholesterol & 42 & 73 & $\mathrm{mg} / \mathrm{dL}$ & $\mathrm{CD}^{+}$ & 20.0 & 36.0 & $\%$ \\
\hline Triglycerides & 106 & 69 & $\mathrm{mg} / \mathrm{dL}$ & $\mathrm{CD}^{+}{ }^{+}$HLA-DR ${ }^{+}$ & 8.0 & 13.3 & $\%$ \\
\hline Urea nitrogen & 8.0 & 14 & $\mathrm{mg} / \mathrm{dL}$ & $\mathrm{CD} 20^{+}$ & --- & 11.0 & $\%$ \\
\hline Creatinine & 0.40 & 0.52 & $\mathrm{mg} / \mathrm{dL}$ & HLA typing & & & \\
\hline Uric acid & 3.0 & 3.6 & $\mathrm{mg} / \mathrm{dL}$ & & A11 & A26 & \\
\hline Sodium & 134 & 136 & $\mathrm{mEq} / \mathrm{L}$ & & A24 & A33 & \\
\hline Potassium & 4.0 & 4.5 & $\mathrm{mEq} / \mathrm{L}$ & & D & DR9 & \\
\hline Chlorides & 99 & 102 & $\mathrm{mg} / \mathrm{dL}$ & & DR4 & DR13 & \\
\hline Selorogy & & & & & DRB1 & DRB1 & \\
\hline ESR & 16 & 48 & $\mathrm{~mm} / \mathrm{hr}$ & & $* 0405$ & *0901 & \\
\hline CRP & 0.02 & 0.05 & $\mathrm{mg} / \mathrm{dL}$ & & DRB1 & DRB1 & \\
\hline $\mathrm{RF}$ & 52 & 383 & $\mathrm{U} / \mathrm{mL}$ & & $* 0406$ & *1302 & \\
\hline ANA & $(-)$ & $\times 160$ & & & DQB1 & DQB1 & \\
\hline Anti-CCP Abs & --- & $<0.6$ & $\mathrm{U} / \mathrm{mL}$ & & *0302 & *0303 & \\
\hline Anti-SS-A Abs & $(-)$ & 128.8 & index & & DQB1 & DQB1 & \\
\hline Anti-SS-B Abs & $(-)$ & 133.1 & index & & $*_{0401}$ & $* 0604$ & \\
\hline
\end{tabular}

ALT: aspartate aminotransferase, ALT: alanine aminotransferase, LDH: lactate dehydrogenese,

ALP:alkaline phosphatase, $\gamma$-GTP: $\gamma$-glutamyl transpepetidase, ESR: erythrocyre sedimentation rate, CRP: C-reactive protein, RF: rheumatoid factor, ANA: anti-nuclear antibodies, sIL-2R: soluble IL-2 receptor, FBG: fasting blood glucose

(S- and U-CPRs) were within normal range. Liver transaminases were slightly elevated and HCV-RNA was still detected. Rheumatoid factor was positive, whereas anti-nuclear antibodies (ANA) were not. Thyroid functions were normal and thyroid-associated autoantibodies (anti-thyroid peroxidase antibodies: TPO Abs, anti-thyroglobulin antibodies: TgAbs) were not detected. The HLA DNA types were DRB $1 * 0405$, DQB $1 * 0401$. Her clinical course is shown in Fig. 1. She initially received subcutaneous injection of insulin aspart at a dose of 10 units/day. Fasting blood glucose levels were stable at nearly $130 \mathrm{mg} / \mathrm{dL}$ at a dose of 18 units/ day of insulin aspart without induction of NPH insulin. HbA ${ }_{1 \mathrm{c}}$ levels were gradually reduced. Withdrawal from insulin injection was possible one year after the onset of T1DM. HOMA- $\beta$ value was increased, indicating the recovery of insulin secretion from pancreatic $\beta$ cells. The GADAb titers were decreased to $7,340 \mathrm{U} / \mathrm{mL} 4$ years after the onset of $\mathrm{T} 1$ DM.

\section{Case 2}

A 67-year-old woman was newly diagnosed with chronic hepatitis $\mathrm{C}$ on health examination in 2002. There was no family history of DM and she had no drinking habit. She had received a blood transfusion at the time of delivery. Peg-IFN- $\alpha 2 \mathrm{a}(180 \mu \mathrm{g}$ once a week) or peg-IFN- $\alpha 2 \mathrm{~b}(1.5$ $\mu \mathrm{g} / \mathrm{kg}$ once a week) plus ribavirin were administered in a clinic from Juanuary 2005 to April 2006. Re-administration of the agents was started in August 2006. Four months after the beginning of the second treatment, thirst and general malaise appeared. The examination in January 2007 revealed hyperglycemia $(575 \mathrm{mg} / \mathrm{dL})$. She received treatment for diabetes with insulin aspart and NPH insulin. She was admitted 


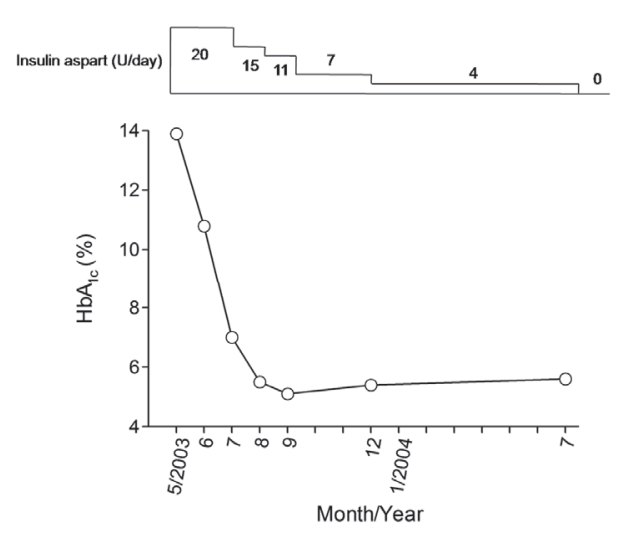

Figure 1. Clinical course in Case 1. Demand of exogenous insulin gradually decreased with the improvement of glycemic control.

to our hospital because she had repeated hypoglycemic attacks. She did not have DM prior to IFN therapy. She was $142.6 \mathrm{~cm}$ tall and weighed $40.5 \mathrm{~kg}$ (BMI $19.9 \mathrm{~kg} / \mathrm{m}^{2}$ ). She also suffered from dry eyes, difficulty in swallowing, and arthralgia of bilateral fingers and knees without swelling of the joints. In the laboratory data shown in Table $1, \mathrm{~S}$ - and U-CPRs were low. GAD Abs were positive. Liver transaminases were within normal range and HCV-RNA was not detected although lymphopenia was found. Rheumatoid factor and anti-SSA/SSB antibodies were all positive. Sjögren's syndrome was finally diagnosed based on decreased secretion of saliva and tears, ultrasonographic findings of chronic inflammation in salivary glands, and infiltration of chronic inflammatory cells in biopsy specimen of the labial glands. Hashimoto's thyroiditis (HT) with adenomatous goitor was also diagnosed based on positive TPO and Tg Abs and diffuse swollen thyroid with nodules in ultrasonography. HLA DNA typing revealed DRB1*0901, DQB1*0303. Her clinical course is shown in Fig. 2. She received treatment with insulin aspart (14 U/day soon before meals) and NPH insulin (12 U/day before breakfast and bedtime), resulting in stable blood glucose levels at 150 to $190 \mathrm{mg} / \mathrm{dL}$ before meals. However, control of blood glucose levels after discharge was unstable again because of repeated hyperglycemia and hypoglycemia, leading to high $\mathrm{HbA}_{1 \mathrm{C}}$ levels. To improve the condition NPH insulin was replaced with insulin glargine due to the improved efficacy of insulin glargine compared with $\mathrm{NPH}$ insulin as intensive replacement of basal insulin in patients with difficult glycemic control with NPH insulin. Titers of GAD Abs were temporally reduced to $656 \mathrm{U} / \mathrm{mL}$, but became elevated again to $1,150 \mathrm{U} / \mathrm{mL} 17$ months after admission.

\section{Discussion}

Chronic HCV infection causes a variety of autoimmune manifestations such as autoimmune thyroid diseases (ATD) and Sjögren's syndrome (SS). HCV-RNA was detected in thyroid and salivary gland tissues from patients with chronic

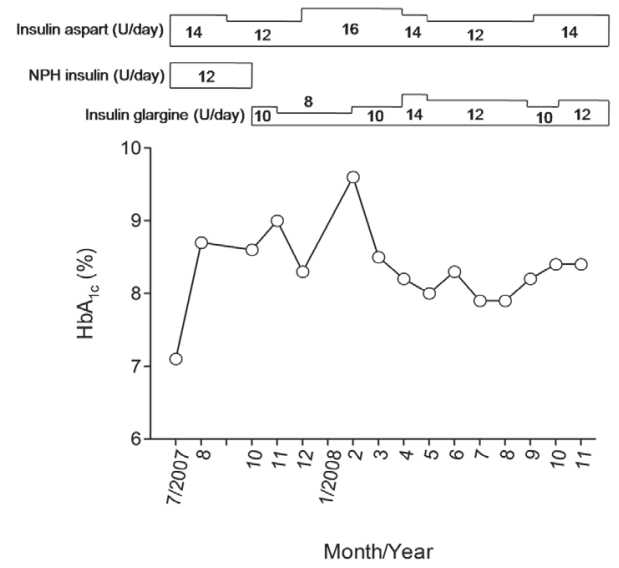

Figure 2. Clinical course in Case 2. Glycemic control was brittle in spite of basal-bolus insulin therapy.

$\mathrm{HCV}$ infection, indicating $\mathrm{HCV}$ per se has some role in the formation of diseases $(2,3)$. $\mathrm{HCV}$ is also present in human pancreatic $\beta$ cells and it is associated with morphological cell changes and reduced glucose-stimulated insulin release (4). However, the onset of T1DM is less frequent than type $2 \mathrm{DM}$ in chronic $\mathrm{HCV}$ infection (5). IFN therapy for chronic hepatitis $\mathrm{C}$ can increase the risk for developing DM. Fabris et al (6) noted that the positivity rate of pancreaticassociated autoantibodies was $3 \%$ before IFN therapy, whereas rose to $7 \%$ after therapy. IFN- $\alpha$ is a primary initiator of the type 1 diabetic process not only in mice but also in humans (7).

The correlation between IFN therapy-induced T1DM and HLA class II alleles has been reported. HLA haplotypes associated with susceptibility to T1DM were found in $44-89 \%$ of the patients with IFN therapy-related T1DM $(6,8)$. The susceptibility is linked to DRB $1 * 0405-\mathrm{DQB} 1 * 0401$, DRB1 *0802- DQB $1 * 0302$, and DRB $1 * 0901-\mathrm{DQB} 1 * 0303$ in the almost all Japanese patients of IFN therapy-related T1 DM (9). In the present cases, the patients had the susceptible HLA alleles although the haplotypes were not been examined, and overt DM with positive GAD Abs was first found after treatment with IFN- $\alpha$. The organ-specific autoantibodies associated with ATD and SS were also detected in Case 2. It was not clear whether these autoantibodies were detected before treatment. In a previous report, patients who were initially positive for organ-specific autoantibodies and those who seroconverted were at high risk of developing clinical autoimmune diseases after treatment with IFN- $\alpha$ (10). However, a group showed that only 2 (22.2\%) of 9 patients with T1DM caused by treatment with IFN- $\alpha$ and ribavirin had T1DM-associated autoantibodies before treatment. In addition, TPO Abs were negative in all patients who developed T1DM and one $(0.5 \%)$ of them had hypothyroidism due to thyroiditis (8). Therefore the occurrence of T1DM does not seem to be always predicted through autoantibodies detected before treatment with IFN.

The characteristics of the two cases are shown in Table 2. Each case followed a distinct clinical course. It is interesting 
Table 2. Clinical Features of Cases

\begin{tabular}{|c|c|c|c|}
\hline & Case 1 & Case 2 & Schreuder et al.[8] \\
\hline Sex/Age of onset & $\mathrm{F} / 46$ & $\mathrm{~F} / 67$ & $5 \mathrm{M} / 25-54$ and $1 \mathrm{~F} / 44$ \\
\hline State of menstruation & Regular & Menopause & Not described \\
\hline DM in family & No & No & Yes in 4 patients \\
\hline HCV genotype & $1 b$ & $1 \mathrm{~b}$ & $1,3,3 a$, or 4 \\
\hline \multirow[t]{4}{*}{ Type of IFN (dose) } & $\begin{array}{l}\text { Peg-IFN- } \alpha 2 \mathrm{a} \\
(180 \mu \mathrm{g} / \text { week })\end{array}$ & $\begin{array}{l}\text { Peg-IFN- } \alpha 2 \mathrm{a} \\
(180 \mu \mathrm{g} / \text { week })\end{array}$ & $\begin{array}{l}\text { Peg-IFN- } \alpha 2 \mathrm{~b} \\
(1.5 \mu \mathrm{g} / \mathrm{kg} / \text { week })\end{array}$ \\
\hline & $\begin{array}{l}\text { Peg-IFN- } \alpha 2 \mathrm{~b} \\
\quad(80 \sim 150 \mu \mathrm{g} / \text { week })\end{array}$ & $\begin{array}{l}\text { Peg-IFN- } \alpha 2 \mathrm{~b} \\
(1.5 \mu \mathrm{g} / \mathrm{kg} / \text { week })\end{array}$ & $\begin{array}{l}\text { Peg-IFN- } \alpha 2 \mathrm{a} \\
(180 \mu \mathrm{g} / \text { week })\end{array}$ \\
\hline & & & $\begin{array}{l}\text { IFN- } \alpha \\
\text { (6-18 MU daily } \\
\text { up to } 6 \text { weeks ) }\end{array}$ \\
\hline & & & $\begin{array}{l}+ \text { IFN- } \alpha 2 \mathrm{~b} \\
\quad(1.5 \mu \mathrm{g} / \mathrm{kg} / \text { week })\end{array}$ \\
\hline Symptoms & Thirst, loss of weight & Thirst, general fatigue & Polyuria, thirst etc. \\
\hline Onset & $\begin{array}{l}4 \text { weeks after treatment } \\
\text { for } 48 \text { weeks }\end{array}$ & $\begin{array}{l}20 \text { weeks after starting } \\
\text { retreatment }\end{array}$ & $\begin{array}{l}4 \text { weeks after end of treat- } \\
\text { ment or week } 11 \text { to } 22\end{array}$ \\
\hline \multirow[t]{3}{*}{ HLA typing } & A11, A24 & A26, A33 & DR3, DR4 \\
\hline & $\mathrm{DRB} 1 * 0405, \mathrm{DRB} 1 * 0406$ & DRB1*0901, DRB1*1302 & DQ2 \\
\hline & DQB1*0302, DQB1*0401 & DQB1*0303, DQB1*0604 & \\
\hline C-peptide reserved & Yes & No & No or not determined \\
\hline $\begin{array}{l}\text { Positive islet cell } \\
\text { autoantibody }\end{array}$ & GAD & GAD & GAD, IA-2, ICA \\
\hline $\begin{array}{l}\text { Positive other organ- } \\
\text { specific autoantibody }\end{array}$ & Not detected & TPO, Tg, SS-A, SS-B & Not detected \\
\hline Insulin therapy & Temporary & Continuous & $\begin{array}{l}\text { All patients remained } \\
\text { insulin-dependent. }\end{array}$ \\
\hline
\end{tabular}

IA-2: antibodies to insulinoma-associated protein 2, ICA: islet cell antibodies

that endogenous insulin secretion was comparatively preserved at the onset of DM and insulin therapy could be discontinued although titers of GAD Abs were so high in Case 1. Eight $(25.8 \%)$ of 31 patients with T1DM due to treatment with IFN received insulin therapy temporally in one report (6), but all of the patients did in another report (8). HLA serotype A24, which is known to be connected with progressive destruction of pancreatic $\beta$ cells, was detected in the present Case 1 , but $\beta$ cell function was not abolished. There are some reports on clinical remission of IFN therapy-induced T1DM in patients with chronic hepatitis after insulin therapy $(11,12)$. However, the mechanism was not elucidated. An immunological mechanism is important for clinical remission on T1DM. Interleukin-10 (IL-10), which suppresses the helper $\mathrm{T}$ cell function, may influence the disease remission. IL-10 was predominantly secreted in peripheral blood mononuclear cells, especially $\mathrm{CD}^{+}$cells, from patients of T1DM with complete recovery of $\beta$ cell function (13). We also believe that estrogen may be another considerable factor of preserving $\beta$ cell function. 17, $\beta$ estradiol (E2) not only directly protects $\beta$ cells from apoptosis and prevents insulin-deficient DM but also drives the ex- pansion of $\mathrm{CD}^{+} \mathrm{CD} 25^{+}$regulatory $\mathrm{T}$ cells, which are essential to suppress autoreactive effector $\mathrm{T}$ cell function $(14,15)$. In the premenopausal patient in Case $1, \beta$ cells may be preserved by secretion of IL-10 and/or estrogen, whereas in the postmenopausal patient with other organ-specific autoimmunity as in Case 2, lasting autoimmune responses superior to immunosuppressive actions of both may be associated with poor clinical remission. We need to verify the relationship between clinical remission and secretion of IL-10 and/or estrogen by case accumulation because there are not any previous reports to show it.

T1DM is an important adverse effect of IFN therapy for chronic HCV infection which affects the patients' quality of life. Currently there are no reliable markers for predicting the development and progression of IFN therapy-induced T1DM. Therefore, we should pay close attention to the appearance of islet-associated autoantibodies and perform the estimation of endogenous insulin secretion and glucose tolerance before IFN therapy or during its interruption for the early detection of the onset of T1DM. Also, in the treatment of T1DM it may be necessary to proceed with consideration of the immunological or hormonal status of the patient.

\section{References}

1. Baccala R, Kono DH, Theofilopoulos AN. Interferons as pathogenic effectors in autoimmunity. Immunol Rev 204: 9-26, 2005.
2. Bartolomé J, Rodriguez-Inigo E, Quadros $P$, et al. Detection of hepatitis $\mathrm{C}$ virus in thyroid tissue from patients with chronic $\mathrm{HCV}$ 
infection. J Med Virol 80: 1588-1594, 2008.

3. Nordmark G, Alm GV, Ronnblom L. Mechanisms of Disease: primary Sjögren's syndrome and the type I interferon system. Nat Clin Pract Rheumatol 2: 262-269, 2006.

4. Masini M, Campani D, Boggi U, et al. Hepatitis C virus infection and human pancreatic beta-cell dysfunction. Diabetes Care 28: 940-941, 2005.

5. Chen LK, Chou YC, Tsai ST, Hwang SJ, Lee SD. Hepatitis C virus infection-related Type 1 diabetes mellitus. Diabet Med 22: 340-343, 2005.

6. Fabris P, Floreani A, Tositti G, Vergani D, De Lalla F, Betterle C. Type 1 diabetes mellitus in patients with chronic hepatitis $\mathrm{C}$ before and after interferon therapy. Aliment Pharmacol Ther 18: 549-558, 2003.

7. Li Q, Xu B, Michie SA, Rubins KH, Schreriber RD, McDevitt HO. Interferon-alpha initiates type 1 diabetes in nonobese diabetic mice. Proc Natl Acad Sci USA 105: 12439-12444, 2008.

8. Schreuder TC, Gelderblom HC, Weegink CJ, et al. High incidence of type 1 diabetes mellitus during or shortly after treatment with pegylated interferon alpha for chronic hepatitis $\mathrm{C}$ virus infection. Liver Int 28: 39-46, 2008.

9. Watanabe J, Yamauchi T. A case of type 1 diabetes mellitus with high titer anti-GAD antibody after combined interferon and ribavirin therapy for chronic hepatitis C. Tonyobyo (Diabetes) 50: 753-
757, 2007 (in Japanese, Abstract in English).

10. Betterle C, Fabris $P$, Zanchetta R, et al. Autoimmunity against pancreatic islets and other tissues before and after interferon-alpha therapy in patients with hepatitis $\mathrm{C}$ virus chronic infection. Diabetes Care 23: 1177-1181, 2000.

11. Waguri M, Hanafusa $T$, Itoh $N$, et al. Occurrence of IDDM during interferon therapy for chronic viral hepatitis. Diabetes Res Clin Pract 23: 33-36, 1994.

12. Shiba T, Morino Y, Tagawa K, Fujino H, Unuma T. Onset of diabetes with high titer anti-GAD antibody after IFN therapy for chronic hepatitis. Diabetes Res Clin Pract 30: 237-241, 1995.

13. Karges B, Durinovic-Bello I, Heinze E, Debatin KM, Boehm B, Karges W. Immunological mechanisms associated with long-term remission of human type 1 diabetes. Diabetes Metab Res Rev 22: 184-189, 2006.

14. Le May C, Chu K, Hu M, et al. Estrogens protect pancreatic betacells from apoptosis and prevent insulin-deficient diabetes mellitus in mice. Proc Natl Acad Sci USA 103: 9232-9237, 2006.

15. Prieto GA, Rosenstein Y. Oestradiol potentiates the suppressive function of human CD4 CD25 regulatory $\mathrm{T}$ cells by promoting their proliferation. Immunology 118: 58-65, 2006.

(C) 2010 The Japanese Society of Internal Medicine

http://www.naika.or.jp/imindex.html 